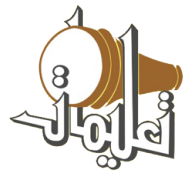

\title{
ARSITEKTUR RUMAH PERAHU: KAJIAN KOMPARATIF RUMAH PERAHU MUARA BUNGO DENGANRUMAH TINGGI ROKAN HULU
}

\author{
Rohul Kana Hilman, S.Sos \\ Asyhadi Mufsi Sadzali, S.S.,M.A \\ Universitas Jambi \\ email: asyhadi_mufsi@unja.ac.id
}

\begin{abstract}
Traditional houses in Sumatra are generally built in the form of stilt houses. A stilt house located in Tanah Periuk Village, district of Tanah Sepenggal Lintas, was built like a boat. Its left and right parts are adorned with decorative patterns in the form of tendrils shaped like the stern and bow of the boat. Meanwhile, the stilt house in Riau, located in Rokan Koto Ruang Village, district of Rokan IV Koto, was built long in shape. Its left and right parts are decorated with tendril patterns in the shape of stern and bow of the boat. Both houses are then compared with comparative morphological analysis, comparative historical analysis and comparative cultural analysis. After that, the resulting data are going through interpretation phase. Using the architecturalarchaeological approach, a hypothesis is then proposed: the architectural differences between the two regions as shown in its stilt houses are due to religious comprehension, tradition and maritime and agrarian lifestyle.
\end{abstract}

Keywords: Archaeology, Boat, Comparative, Stilt House,

\begin{abstract}
Abstrak
Rumah tradisional yang terdapat di Sumatera umumnya berbentuk kolong atau berpanggung. Salah satu rumah panggung yang terdapat di Sumatera yaitu rumah tradisional Jambi dan rumah tradisional Riau. Rumah panggung yang terdapatdi Jambi salah satunya berada di Desa Tanah Periuk di Kecamatan Tanah Sepenggal Lintas. Rumah ini berbentuk kolong dan badannya hampir menyerupai lengkungan perahu dan terdapat bagian sisi ujung kiri dan kanan badan terdapat motif hias sulur-suluran yang hampir menyerupai buritan dan haluan perahu. Sedangkan rumah tradisional di Riau salah satunya terdapat di Desa Rokan Koto Ruang, Kecamatan Rokan IV Koto. Rumah tersebut berbentuk memanjang dan bagian ujung sisi kiri dan kanan badan rumah terdapat motif hias sulur-suluran yang menyerupai buritan dan haluan perahu. Kedua rumah tradisionalpada dua wilayah yang berbeda dilakukan kajian komparatifyang terdiri dari komparatif secaramorfologi, komparatif sejarah dan komparatif analisis kebudayaan. Selanjutnya data komparatif analisis tersebut dimasukkan ke tahapan interpretasi. Dari proses analisis data dengan pendekatan arkeologi arsitektural, dapat
\end{abstract}




\section{disusun suatu hipoteasa, bahwa arsitktur tardisonal dikedua tempat dipengaruhi oelh tiga akar kebudayaan; yakni religi, tradisi, dan corak hidup maritime dan agraris.}

Kata Kunci: Arkeologi, komparatif, rumah, perahu,

\section{PENDAHULUAN}

Indonesia adalah negara kepulauan berbentuk maritim. Sebagai negara kepulauan, Indonesia memiliki berbagai tinggalan benda-benda bersejarah yang berada di air dan daratan, baik benda lepas di air seperti perahu maupun tinggalan daratan salah satunya berupa bangunan yang berbentuk rumah hunian. Salah satu tinggalan benda yang sudah digunakan dari masa Prasejarah sampai sejarah ialah perahu. Tinggalan ini dapat diperkuat dengan berbagai penelitian arkeologi. Salah satu penelitian arkeologi berupa tinggalan artefak perahu dilakukan oleh Pierre-Yves Manguin dalam Yadi Mulyadi. Menurut Yadi Mulyadi, Pierre yang seorang pakar sejarah maritim dari Perancis melakukan penelitian perahu Kuno tepatnya berada di Indonesia pada tahun $1997^{1}$. Tinggalan perahu kuno tersebut dikategorikan ke dalam tinggalan benda arkeologi maritim.

Pengetahuan orang Austronesia mengenai teknologi pelayaran semakin berkembang di daerah Asia Tenggara Kepulauan. Hal ini dapat diketahui dengan mengamati persamaan bentuk perahu yang digunakan di Kepulauan Solomon dan Botel Tobago (bernama yamis) yang terdapat di Maluku (bernama orembal). Selain menggunakan perahu, masyarakat Prasejarah juga sudah mengenal arsitektur rumah. Seperti yang diungkapkan oleh R.P Soejono, kemungkinan besar dahulu ada

\footnotetext{
${ }^{1}$ Yadi Mulyadi, Kemaritiman, Jalur Rempah dan Warisan Budaya Bahari Nusantara. Universitas Hasanudin, Makasar, 2016, hal. 1.
}

sejumlah orang berbahasa Austronesia tinggal di daerah pinggir sungai di Cina Selatan dan Vietnam Utara pada pertengahan milenium ke-4 $\mathrm{SM}^{2}$. Persebaran orang-orang Austronesia tersebut di perkuat dengan teori yang dikemukakan oleh Peter Bellwood yaitu daerah asal bangsa Austronesia adalah Taiwan dan pantai Cina bagian selatan. Kawasan tersebut oleh beberapa ahli linguistik dianggap sebagai tempat asal bahasa proto- Austronesia ${ }^{3}$.

Orang-orang Austronesia yang sudah menyebar di beberapa daerah Asia Tenggara mulai menyesuaikan diri dengan iklim tropis yang melanda daerah tersebut ${ }^{4}$. Iklim tersebut berdampak pada masyarakat Austronesia yang mulai membentuk arsitektur tempat hunian yang cocok dengan iklim tropis. Ciri-ciri dari hunian beriklim tropis merujuk pada ciri-ciri bangunan Austronesia oleh Allen G Noble yaitu Bentuk bangunan Rumah Austronesia biasanya terdiri atas bangunan persegi empat, berdiri di atas tiang-tiang, beratap ilalang. Adapun bentuk pintu masuk berupa tangga dari batang pohon yang ditakik dan ada perapian dengan rak di atasnya untuk kayu bakar dan penyimpanan. Secara umum dilihat dari bentuk bangunan rumah tradisional di Indonesia berkonsep pada arsitektur Austronesia dengan memiliki ciri-ciri berbentuk

\footnotetext{
Gunawan Tjahjono,Indonesia Heritage: Arsitektur. Buku Antar Bangsa, Jakarta Agung Offset, Jakarta, New York: Palgrave Macmillan, a division of St Martin's Press, 2002, hal. 10.

${ }^{3}$ Sofwan Noerwidi,Proses Kolonisasi Bangsa Austronesia di Kawasan Maluku Utara, hal.4.

${ }^{4}$ Gunawan Tjahjono, Op chit, hal. 12
} 
persegi, memanjang kesamping atau kebelakang, berbentuk panggung, berbahan kayu atau bambu ${ }^{5}$. Ciri-ciri bangunan yang dipaparkan oleh Peter Belwood mulai menyebar hampir di daerah Indonesia dengan bercirikan rumah panggung atau berkolong.Persebaran rumah Austronesia yang bercirikan rumah panggung atau berkolong, terdapat di daerah Sumatera tepatnya berada di Provinsi Jambi dan Provinsi Riau. Tepatnya rumah berbentuk perahu yang terdapat di Desa Tanah Periuk dan rumah Tinggi di Desa Rokan Koto Ruang wilayah Provinsi Riau.

Rumah Perahu yang berada Di Desa Tanah Periuk, Kecamatan Tanah Sepenggal Lintas, Kabupaten Muara Bungo, Jambi, memiliki keunikan yang sangat bervariasi dengan ciri khas dan nilai-nilai budaya yang sekaligus merupakan kebanggaan masyarakat Bungo. Salah satu hal unik dari rumah Perahu yaitu penyebutan lokal oleh mayarakat setempat dengan sebutan rumah Perahu. Keunikan penyebutan lokal tersebut di dasari oleh keunikan dari bentuk rumah Perahu yang hampir menyerupai perahu pada bagian badan dan atap.

Secara umum bentuk dari rumah Perahu yaitu persegi empat dan melengkung hampir menyerupai perahu, dengan bahan dasar kayu ulim, serta atap atau bubungan dibuat seperti perahu dengan ujung bagian atas melengkung yang biasa disebut Kajang Lako. Selain keunikan penyebutan lokal dan bentuk dari rumah Perahu di Tanah Periuk, keunikan penyebutan lokal serta bentuk rumah juga terdapat pada rumah Tinggi yaitu di Desa Rokan Koto Ruang, Kecamatan Rokan IV Koto, Kabupaten Rokan Hulu, Riau.

Penyebutan lokal rumah Tinggi oleh mayarakat setempat dikenal juga dengan sebutan rumah Tinggi. Keunikan penyebutan lokal tersebut

${ }^{5}$ Allen G Noble. Traditional Buildings: A Global Survey of Structural Forms and Cultural Functions, 2007, hal.3 didasari juga dari bentuk rumah Tinggi berdasarkan komponennya yaitu memiliki pola persegi panjang pada bagian depannya, lalu pada bagian depan terdapat bagian menonjol seperti serambi. Sedangkan bagian badan dari rumah Tinggi ini hampir menyerupai bentuk dari perahu. Serta atapnya berbentuk bumbung yang curam yang disebut Lipat Kajang yang berfungsi memudahkan curahan air hujan. Melihat fakta di lapangan, terkait dua rumah tradisional tersebut yakni rumah Perahu dan rumah Tinggi, terdapat hal-hal menarik ditinjau dari kajian arkeologi, hal-hal menarik tersebut dari kedua bangunan rumah diantaranya, 1) secara bentuk bangunan, berdasarkan pemaparan pada pembahasan sebelumnya diketahui bahwa bentuk kedua rumah tersebut rumah Perahu dan rumah Tinggi menyerupai bentuk perahu. 2) rumah tersebut terdapat ornamen-ornamen yang mempunyai ciri-ciri kebudayaan yang berbau maritim, misalnya pada rumah Tinggi terdapat hiasan ukiran berbentuk naga. 3) Hal selanjutnya yang menarik dari penelitian ini yaitu ingin melihat adanya percampuranpercampuran berbagai kebudayaan dan juga ada pengaruh dengan adaptasi lingkungan, kemudian mempengaruhi motif hias dan tata ruang dari bangunan rumah Perahu dan rumah Tinggi. 4) hal yang menarik lainnya dari penelitian ni yaitu ingin melihat seberapa besar pengaruh aspek arsitektur kebudayaan austronesia yang bersifat maritim dan agraris, yang diwariskan terhadap rumah Perahu dan rumah Tinggi. 5) dan terakhir kajian tentang arsitektur kedua rumah tersebut masih sangat minim dan masih banyak yang belum melakukan kajian secara mendalam, terlebih persoalan aspek-aspek budaya ayang mempengaruhi bentuk arsitektur.

\section{METODOLOGI PENELITIAN}

Metode penelitian yang akan digunakan menggunakan metode arkeologi, dengan penelitian 
pendekatan komparatif. Penelitian komparatif merupakan studi yang dilakukan untuk menemukan suatu gejala baik itu persamaan maupun perbedaan dengan cara membandingkan data yang ada seperti komparatif analisis morfologi, komparatif analisis sejarah dan komparatif analisis kebudayaan.

\section{PEMBAHASAN}

\section{Analisis Runah Perahu dan Rumah} Tinggi

Analisis data yang akan digunakan yaitu menggunakan kajian komparatif atau perbandingan. Analisis komparatif yaitu bersifat membandingkan persamaan dan perbedaan dua atau lebih fakta-fakta dan sifat-sifat objek yang di teliti berdasarkan kerangka pemikiran. Adapun analisis komparatif yang dilakukan yaitu tentang perbandingan persamaan dan perbedaan morfologi Rumah Perahu dan Rumah Tinggi, perbandingan dari persamaan dan perbedaan sejarah Rumah Perahu dan Rumah Tinggi dan perbandingan dai segi kebudayaan Rumah Perahu dan Rumah Tinggi. Hasil perbandingan dari ketiga analisis tersebut akan ditampilkan pada tabel dibawah ini.

a. Analisis KomparatifMorfologi

Analisis morfologi ini dilakukan pengukuran terhadap bangunan keseluruhan dan unsur-unsur bangunannya. Perbandingan morfologi Rumah Perahu dan Rumah Tinggi yaitu terdiri dari perbandingan persamaan dan perbedaan bentuk kedua rumah tersebut yang terdiri dari bagian kaki, tubuh atau badan dan atap rumah. Adapun perbandingan kedua rumah tersebut antara lain terdapat pada tabel dibawah ini.

Tabel 1. Sketsa Perbandingan Bentuk Kaki Rumah Perahu dan Rumah Tinggi.

\begin{tabular}{|c|c|c|}
\hline N & Sketsa & Sketsa Komponen- \\
o & Komponen- & Komponen Kaki \\
& Komponen & Rumah Tinggi \\
& Kaki Rumah & \\
\hline
\end{tabular}

\begin{tabular}{|c|c|c|}
\hline & Perahu & \\
\hline 1. & $\begin{array}{l}\text { Sketsa. 1. } \\
\text { Umpak. } \\
\text { Diolah.Alvi } \\
\mathrm{n} \\
\text { Ramadhan. } \\
\text { 2018) }\end{array}$ & $\begin{array}{l}\text { (Sketsa. 2. Umpak. } \\
\text { Yuhani. 2019) }\end{array}$ \\
\hline 2. & $\begin{array}{l} \\
\text { (Sketsa. } \\
\text { 3.Tiang. } \\
\text { Diolah. } \\
\text { Gavin Rizky } \\
\text { Ananda. } \\
\text { 2018) }\end{array}$ & \begin{tabular}{|l||} 
\\
(Sketsa. 4. Tiang \\
Biasa. Yuhani. \\
2019)
\end{tabular} \\
\hline 3. & $\begin{array}{c}\text { n } \\
\text { (Sketsa. 5. } \\
\text { Tangga . } \\
\text { Ramadhan. } \\
\text { 2018) }\end{array}$ & $\begin{array}{c}\text { (Sketsa. 6. Tangga } \\
\text { tampak depan. } \\
\text { Yuhani. 2019) }\end{array}$ \\
\hline
\end{tabular}

Perbandingan persamaan dan perbedaan dari bagian kaki kedua rumah ini, yaitu rumah Perahu dan rumah Tinggi dapat disimpulkan bentuk morfologinya sebagai berikut.

1. Pada bagian umpak rumah Perahu berbentuk persegi empat dan berbahan semen. Umpak tersebut terdiri dari 17 buah. Sedangkan umpak rumah Tinggi 
berbentuk persegi empat dan berbahan semen keramik, namun umpaknya hanya terdapat satu dan menyambung pada semua tiang bagian dasar dari rumah tersebut.

2. Pada bagian tiang rumah Perahu terdiri dari 17 yang masingmasing terdapat tiang biasa dan tiang ornamen. Begitu juga dengan tiang rumah Tinggi yang memiliki jumlah 18 terdapat tiang biasa dan ornamen.

3. Rumah Perahu tidak memiliki teras hanya memiliki tangga langsung yang dibatasi kayu sebagai pembatas tangga dan area dalam rumah, sedangkan rumah Tinggi memiliki teras yang berbentuk persegi empat sebagai salah satu alternatif sebagai pembatas antar tangga dan area dalam rumah.

Tabel 2. Sketsa Perbandingan Bentuk Badan Rumah Perahu dan Rumah Tinggi.

\begin{tabular}{|c|c|c|}
\hline $\begin{array}{l}\mathrm{N} \\
\mathrm{O}\end{array}$ & $\begin{array}{c}\text { Sketsa } \\
\text { Komponen- } \\
\text { Komponen } \\
\text { Badan Rumah } \\
\text { Perahu }\end{array}$ & $\begin{array}{c}\text { Sketsa } \\
\text { Komponen- } \\
\text { Komponen } \\
\text { Badan Rumah } \\
\text { Tinggi }\end{array}$ \\
\hline 4. & $\begin{array}{c}\text { (Sketsa. } 7 .|| \\
\text { Pintu. } \\
\text { Diolah.Alvin } \\
\text { Ramadhan. } \\
\text { 2018) }\end{array}$ & $\begin{array}{l}\text { (Sketsa. 8. } \\
\text { Pintu. Yuhani. } \\
\text { 2019) }\end{array}$ \\
\hline 5. & $\begin{array}{c}= \\
\text { Sketsa. } 9 . \\
\text { Jendela . } \\
\text { Diolah.Alvin }\end{array}$ & 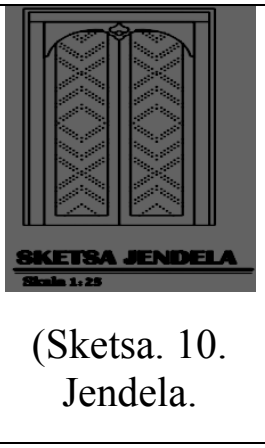 \\
\hline
\end{tabular}

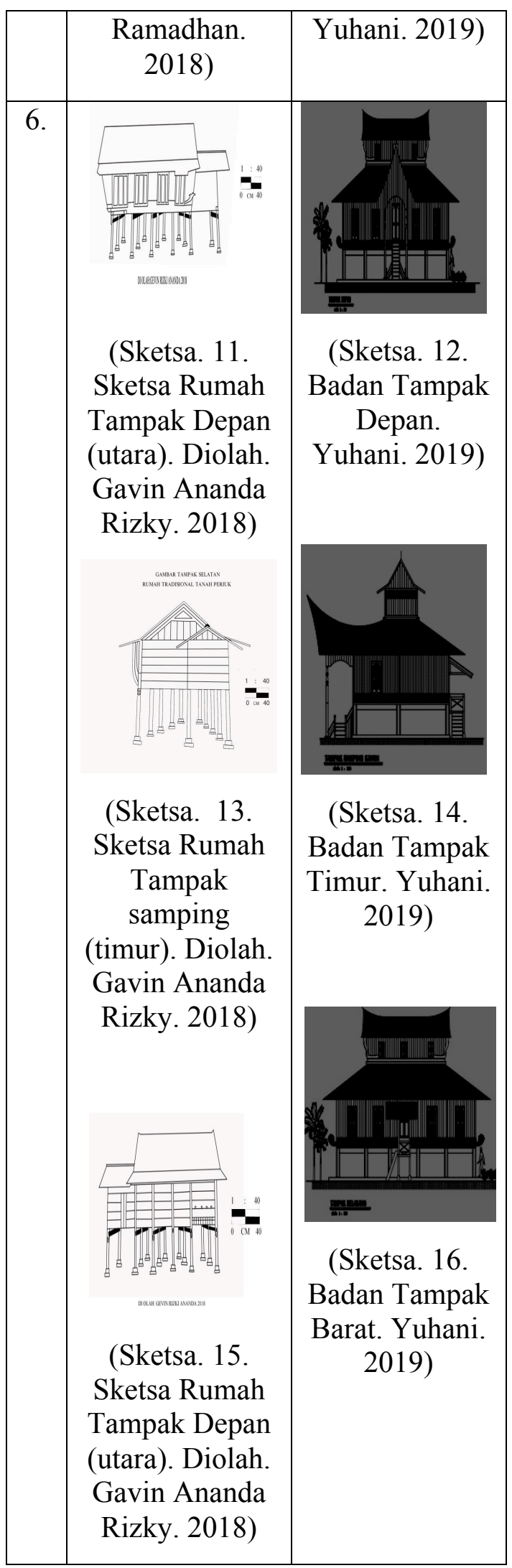




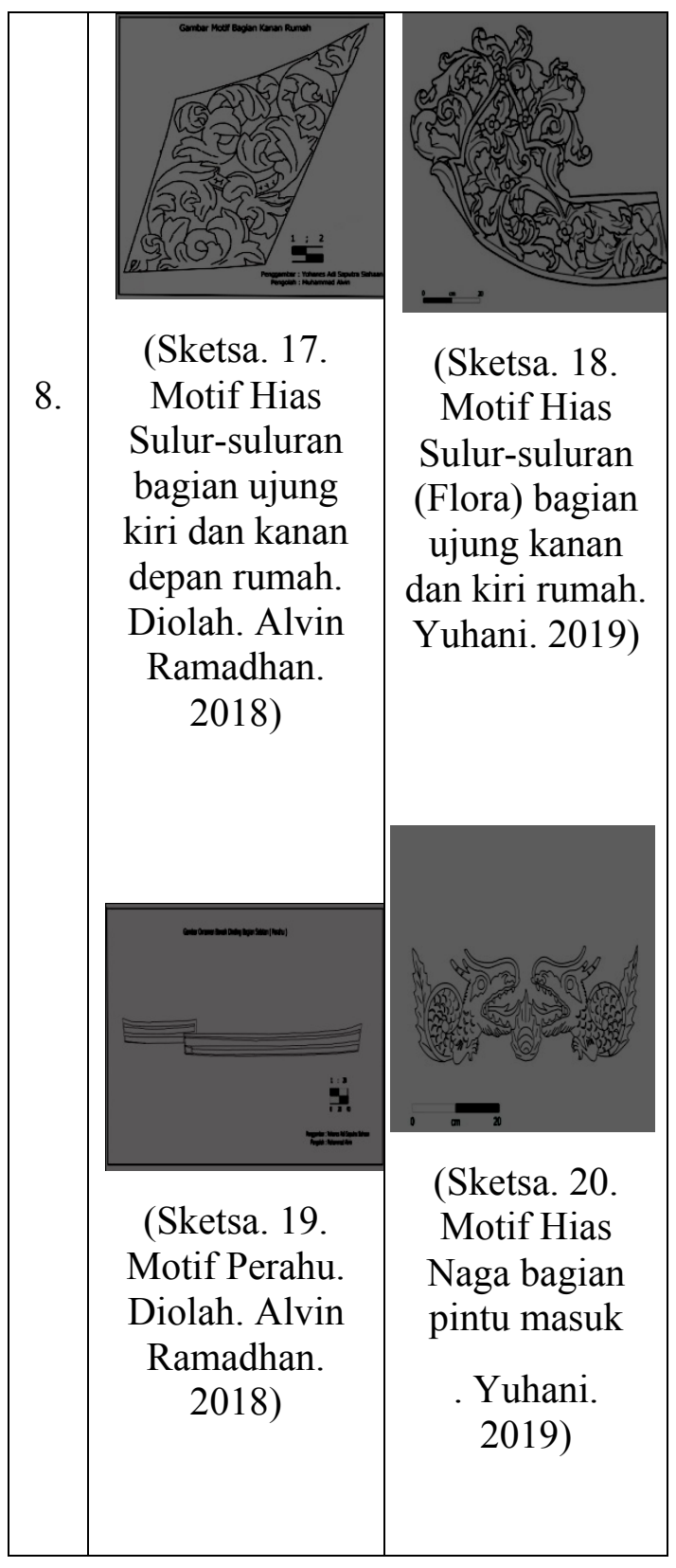

Perbandingan persamaan dan perbedaan dari bagian badan kedua rumah ini, yaitu rumah Perahu dan rumah Tinggi dapat disimpulkan bentuk morfologinya sebagai berikut.

1. Pada pintu rumah Perahu dan rumah Tinggi berbentuk memanjang persegi empat.

2. Jendela rumah Perahu yaitu persegi empat dan terdapat motif sulur-suluran pada pengait sedangkan jendela rumah tinggi persegi empat memanjang.

3. Badan rumah Perahu melengkung dan terdapat bagian sisi kiri dan kanan motif hias. Sedangkan badan rumah Tinggi persegi yang terdapat anjung dan motif hias pada sisi kiri dan kanan. Motif hias pada kedua rumah tersebut terdapat pada sisi timur dan barat memiliki persamaan motif yaitu bermotif sulur-suluran.

4. Terdapat beberapa motif pada bagian badan rumah Perahu dan rumah Tinggi diantaranya motif sulur-suluran pada bagian badan rumah Perahu dan rumah Tinggi, motif Naga yang terdapat pada pintu masuk rumah Tinggi.

Tabel 3. Sketsa Perbandingan

Bentuk Ruang Rumah Perahu dan Rumah Tinggi.

\begin{tabular}{|c|c|c|}
\hline $\begin{array}{l}N \\
\mathrm{o}\end{array}$ & $\begin{array}{c}\text { Sketsa } \\
\text { Komponen- } \\
\text { Komponen } \\
\text { Ruang } \\
\text { Rumah } \\
\text { Perahu }\end{array}$ & $\begin{array}{c}\text { Sketsa } \\
\text { Komponen- } \\
\text { Komponen } \\
\text { Ruang Rumah } \\
\text { Tinggi }\end{array}$ \\
\hline 7. & 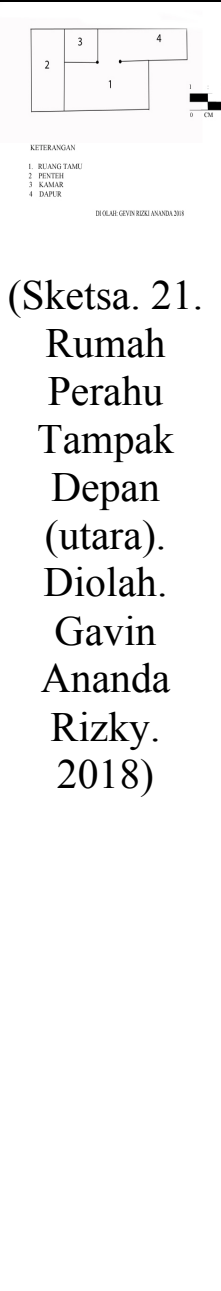 & $\begin{array}{l}\text { Rketsa. 22. } \\
\text { Rumah Tinggi } \\
\text { Ruang Lantai } \\
\text { 1. Diolah. } \\
\text { Yuhani. 2019) } \\
\text { 1. Bagian } \\
\text { Depan: } \\
\text { Ruang } \\
\text { Tamu } \\
\text { 2. Bagian } \\
\text { samping } \\
\text { Kiri } \\
\text { (Timur) } \\
\text { Kantor } \\
\text { Bagian } \\
\text { samping } \\
\text { Kanan } \\
\text { ( Barat) } \\
\text { Kamar. }\end{array}$ \\
\hline
\end{tabular}




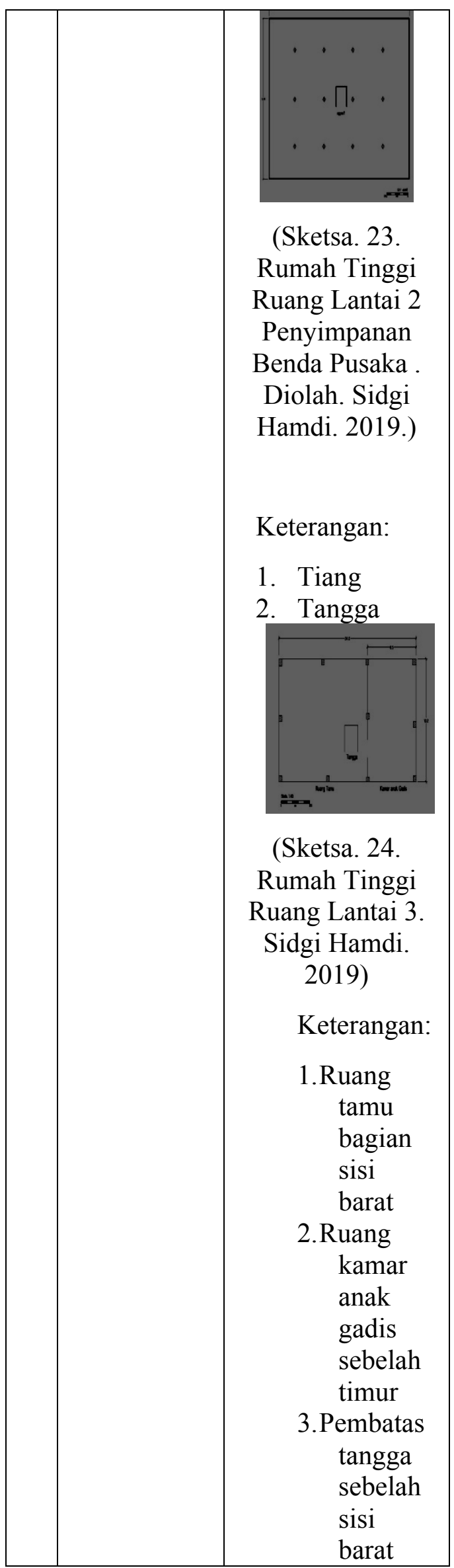

Perbandingan persamaan dan perbedaan dari bagian ruang kedua rumah ini, yaitu rumah Perahu dan rumah Tinggi dapat disimpulkan bentuk morfologinya sebagai berikut.

1. Ruang rumah Perahu terdiri satu lantai dan terdapat ruang tamu yang berpentas (bertingkat), kamar dan dapur,

2. Rumah Tinggi Terdapat tiga lantai terdiri dari ruang tamu, kamar tidur raja, ruang kerja, lantai 2 yaitu sebagai ruang penyimpanan benda pusaka dan lantai tiga terdapat ruang kosong (ruang tamu) pada bagian sisi barat dan ruang kamar anak gadis bagian sisi timur rumah.

b. Analisis KomparatifSejarah

Analisis sejarah dilakukan dengan mencari sumber sejarah tentang tinggalan rumah Perahu di Tanah Periuk dan rumah Tinggi di Rokan Koto Ruang berupa arsip-arsip yang berhubungan dengan rumah dan wawancara dengan beberapa narasumber rumah Perahu di Tanah Periuk dan rumah Tinggi di Rokan Koto Ruang. Adapun daftar sumber sejarah Tanah Periuk yaitu sebagai berikut.

Tabel 4. Perbandingan Kesimpulan Sumber Sejarah Rumah Perahu Tanah Periuk Dan Rumah Tinggi Rokan Koto Ruang.

\begin{tabular}{|c|c|c|}
\hline No & $\begin{array}{l}\text { Sumber Sejarah } \\
\text { Rumah Perahu }\end{array}$ & $\begin{array}{c}\text { Sumber } \\
\text { Sejarah } \\
\text { Rumah Perahu }\end{array}$ \\
\hline 1. & $\begin{array}{l}\text { a. Pendiri dari } \\
\text { rumah } \\
\text { Perahu Desa } \\
\text { Tanah Periuk } \\
\text { ialah } \\
\text { Pakubuwono } \\
\text { atau yang } \\
\text { bergelar Sri } \\
\text { Mangkubumi } \\
\text { yang berasal } \\
\text { dari } \\
\text { Mataram. } \\
\text { b. Para } \\
\text { rombongan } \\
\text { Sri } \\
\text { Mangkubumi } \\
\text { (Pakubuwon }\end{array}$ & 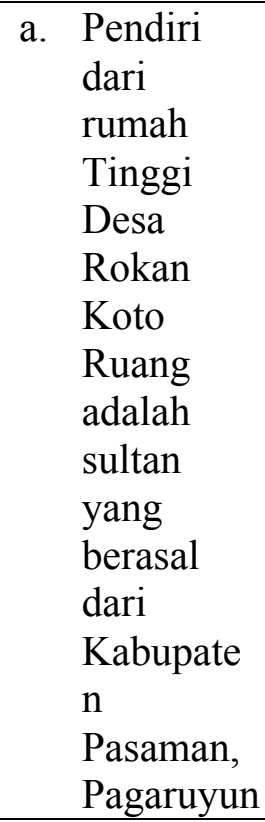 \\
\hline
\end{tabular}




\begin{tabular}{|c|c|c|}
\hline $\begin{array}{l}\text { o) datang ke } \\
\text { Tanah Periuk } \\
\text { pada tahun } \\
1650 \\
\text { Masehi. } \\
\text { c. Alasan Sri } \\
\text { Mangkubumi } \\
\text { pergi dari } \\
\text { tanah } \\
\text { Mataram ke } \\
\text { pulau } \\
\text { Sumatera } \\
\text { khususnya } \\
\text { Jambi dan } \\
\text { Tanah Periuk } \\
\text { ialah karena } \\
\text { Sri } \\
\text { Mangkubumi } \\
\text { beserta } \\
\text { rombongan } \\
\text { penentang } \\
\text { para VOC } \\
\text { Belanda dan } \\
\text { Sultan } \\
\text { Hamangkubu } \\
\text { wono II yang } \\
\text { bersengkong } \\
\text { kol dengan } \\
\text { VOC. }\end{array}$ & c. & $\begin{array}{l}\text { g } \\
\text { Kabupate } \\
\mathrm{n} \text { Tanah } \\
\text { Datar } \\
\text { (Minangk } \\
\text { abau). } \\
\text { Pada } \\
\text { tahun } \\
\text { 1519 } \\
\text { sampai } \\
\text { tahun } \\
\text { 1572, } \\
\text { dilakukan } \\
\text { pengusira } \\
\text { n suku } \\
\text { Sakai di } \\
\text { Rokan } \\
\text { awalnya } \\
\text { dilakukan } \\
\text { oleh Sutan } \\
\text { Seri } \\
\text { Alam, } \\
\text { namun } \\
\text { pengusira } \\
\text { n tersebut } \\
\text { belum } \\
\text { tuntas dan } \\
\text { dilanjutka } \\
\text { n kembali } \\
\text { oleh Raja } \\
\text { yang } \\
\text { keempat } \\
\text { yaitu } \\
\text { Tengku } \\
\text { Sutan } \\
\text { Sepedas } \\
\text { Padi yang } \\
\text { memerinta } \\
\text { h pada } \\
\text { tahun } \\
\text { 1519 } \\
\text { sampai } \\
\text { tahun } \\
\text { 1572, } \\
\text { bersama } \\
\text { dengan } \\
\text { Sutan } \\
\text { Harimau. } \\
\text { Alasan } \\
\text { sutan } \\
\text { Minangka } \\
\text { bau pergi }\end{array}$ \\
\hline
\end{tabular}

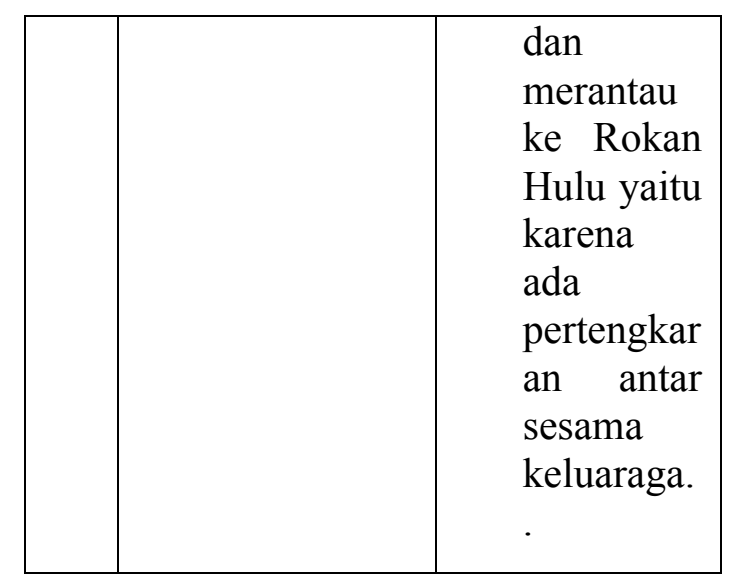

c. Analisis KomparatifKebudayaan Analisis kebudayaan masyarakat dilakukan dengan mengamati atau meninjau langsung ke daerah rumah tradisional Rumah Perahu Tanah Periuk dan Rumah Tinggi Rokan Koto Ruang. Kegiatan tersebut dilakukan untuk melihat dan mengetahui budaya masyarakat sekarang yang akan dikaitkan dengan kebudayaan masyarakat Tanah Periuk dan Rokan Koto Ruang pada masa lalu. Perbandingan Kebudayaan dari kedua daerah rumah yaitu rumah Perahu di Desa Tanah Periuk dan rumah Tinggi di Desa Rokan Koto Ruang. Kebudayaan yang akan dibandingkan yaitu mulai dari upacara adat, tradisi sampai mitos yang berkembang pada kedua daerah tersebut. Adapun perbandingan kedua perbandingan tersebut antara lain terdapat pada tabel di bawah ini.

Tabel 5. Perbandingan

Kebudayaan Rumah Perahu

Desa Tanah Periuk dan

Rumah Tinggi Desa Rokan

Koto Ruang.

\begin{tabular}{|l|l|l|l|}
\hline $\begin{array}{l}\text { N } \\
\text { o. }\end{array}$ & $\begin{array}{l}\text { Kebuday } \\
\text { aan }\end{array}$ & $\begin{array}{l}\text { Kebudaya } \\
\text { an Rumah } \\
\text { Perahu } \\
\text { Tanah } \\
\text { Periuk }\end{array}$ & $\begin{array}{l}\text { Kebuday } \\
\text { aan } \\
\text { Rumah } \\
\text { Tinggi } \\
\text { Rokan } \\
\text { Koto } \\
\text { Ruang }\end{array}$ \\
\hline 1. & Tradisi & $\begin{array}{l}1 . \quad \mathrm{Pa} \\
\text { cu perahu } \\
\text { dilaksanak } \\
\text { an saat hari } \\
\text { raya idul }\end{array}$ & $\begin{array}{l}\text { 1. Pacu } \\
\text { perahu } \\
\text { dilaksana } \\
\text { kan } \\
\text { setiap }\end{array}$ \\
\hline
\end{tabular}




\begin{tabular}{|c|c|c|c|}
\hline & & $\begin{array}{l}\text { fitri, } \\
\text { tepatnya } \\
\text { pada hari } \\
\text { keempat. } \\
\text { Pacu } \\
\text { perahu } \\
\text { tersebut } \\
\text { sudah } \\
\text { menjadi } \\
\text { tradisi } \\
\text { masyarakat } \\
\text { setempat. } \\
\text { 2. } \\
\text { Pembuatan } \\
\text { perahu } \\
\text { biasanya } \\
\text { dilakukan } \\
\text { musyawara } \\
\text { h dan } \\
\text { bergotong } \\
\text { royong } \\
\text { oleh warga } \\
\text { setempat. }\end{array}$ & $\begin{array}{l}\text { lebaran. } \\
2 . \\
\text { Kebuday } \\
\text { aan } \\
\text { dalam } \\
\text { pembersi } \\
\text { han Desa } \\
\text { biasanya } \\
\text { dilakukan } \\
\text { musyawa } \\
\text { rah } \\
\text { apabila } \\
\text { terjadi } \\
\text { tindakan } \\
\text { asusila } \\
\text { atau } \\
\text { hamil di } \\
\text { luar } \\
\text { nikah } \\
\text { wajib } \\
\text { membaya } \\
\text { r denda } \\
\text { berupa } \\
\text { potong } \\
\text { kambing, } \\
\text { musyawa } \\
\text { rah } \\
\text { tersebut } \\
\text { dilakukan } \\
\text { di rumah } \\
\text { Tinggi } \\
\text { setiap } \\
\text { tahunnya } \\
\text { atau yang } \\
\text { dikenal } \\
\text { dengan } \\
\text { cuci } \\
\text { kampung. }\end{array}$ \\
\hline 2. & $\begin{array}{l}\text { Upacara } \\
\text { Adat }\end{array}$ & $\begin{array}{l}\text { Mandi } \\
\text { kayik } \\
\text { dilakukan } \\
\text { saat } \\
\text { memandi } \\
\text { kan bayi } \\
\text { ketika } \\
\text { berumur } \\
1-2 \\
\text { minggu } \\
\text { sejak } \\
\text { kelahiran } \\
\text { nya. }\end{array}$ & $\begin{array}{l}\text { Membaw } \\
\text { a anak } \\
\text { bayi } \\
\text { mandi ke } \\
\text { sungai } \\
\text { oleh } \\
\text { dukun } \\
\text { beranak } \\
\text { ketika } \\
\text { acara } \\
\text { potong } \\
\text { rambut } \\
\text { atau }\end{array}$ \\
\hline
\end{tabular}

\begin{tabular}{|l|l|l|}
\hline & Mandi & akikahan \\
& kayik & yang \\
merupaka & terjadi \\
n upacara & pada \\
adat yang & tahun \\
telah & $1990-$ an. \\
turun & \\
temurun & \\
dari & \\
nenek & \\
moyang & \\
\hline
\end{tabular}

Kandungan Undur Budaya pada Rumah Perahu dan Rumah Tinggi

Intepretasi dapat dikatakan sebagai tafsiran, penjelasan, makna, arti, atau pandangan teoritis terhadap suatu objek yang dihasilkan dari pemikiran mendalam dan sangat dipengaruhi oleh latar belakang orang yang melakukan interpretasi. Jadi, interpretasi yang dilakukan oleh Penulis pada penelitian antara rumah Perahu dan rumah Tinggi berdasarkan rumusan masalah yang merujuk pada teori kebudayaan Clifford Geertz. Setelah dilakukan analisis morfologi, analisis sejarah dan analisis kebudayaan, interpretasi ini mencakup tentang unsur-unsur budaya maritim, budaya agararis dan budaya religi yang terdapat pada bagian rumah Perahu dan rumah Tinggi. Adapun ketiga unsur tersebut akan dipaparkan sebagai berikut.

1. Unsur Budaya Maritim Rumah Perahu Pada dan Rumah Tinggi Budaya maritim yang berada di Desa Tanah Periuk dan Desa Rokan Koto Ruang lebih dominan ke aktivitas pencaharian ikan dengan menggunakan perahu sebagai kendaraan dan aktivitas tradisi lomba pacu perahu yang diadakan setiap setahun sekali pada saat momen lebaran idul fitri pada saat sekarang. Namun, menilik dari kehidupan masa lampau tentang kebudayaan maritim pada Desa Tanah Periuk dan Desa Rokan Koto Ruang, dapat dilihat dari rumah Perahu dan rumah Tinggi. Budaya maritim yang dapat dilihat dari kedua bangunan 
tersebut akan dijelaskan pada tabel dibawah ini.

Tabel. Bagian-Bagian Rumah Yang

Terdapat Budaya Maritim Rumah

Perahu Dan Rumah Tinggi.

\begin{tabular}{|c|l|l|}
\hline No & $\begin{array}{l}\text { Bagian Rumah } \\
\text { Perahu Yang } \\
\text { Terdapat } \\
\text { UnsurMaritim }\end{array}$ & $\begin{array}{l}\text { Bagian Rumah } \\
\text { TinggiYang } \\
\text { Terdapat } \\
\text { UnsurMaritim }\end{array}$ \\
\hline 1. & $\begin{array}{l}\text { Badan rumah } \\
\text { yang } \\
\text { melengkung } \\
\text { berbentuk } \\
\text { lambung } \\
\text { perahu serta } \\
\text { terdapat ujung } \\
\text { kiri dan kanan } \\
\text { motif hias } \\
\text { berupa sulur- } \\
\text { suluran yang } \\
\text { mirip haluan } \\
\text { dan buritan } \\
\text { perahu }\end{array}$ & $\begin{array}{l}\text { Tepasang motif } \\
\text { naga bada } \\
\text { pintu masuk }\end{array}$ \\
\hline
\end{tabular}

Bagian-bagian kedua rumah tersebut yang dianggap sebagai bentuk dari budaya maritim dapat dikatakan sebagai bentuk wujud bahwa budaya maritim sudah ada sejak zaman nenek moyang masyarakat Desa Tanah Periuk dan Desa Rokan Koto Ruang. Bentuk badan rumah dari rumah Perahu dan rumah Tinggi serta dan atap dari rumah Perahu menyerupai bentuk dari perah memiliki pemaknaan dalam bentuk simbol perahu. Pemaknaan dari bentuk simbol perahu yaitu sebagai struktur sosial kemasyarakatan. Motif perahu atau kapal menggambarkan kendaraan legendaris perjalanan nenek moyang dari alam atas menuju dunia, namun dalam pengertian kosmologis yang melambangkan adanya suatu unsur dualisme yang membagi alam semesta atas dua hal atau golongan yang saling bertentangan, misalnya dunia atas dan dunia bawah ${ }^{6}$. Selain pemaknaan

\footnotetext{
${ }^{6}$ Agus S. Ekomadyo, Kayu arra: simbol pohon hayat masyarakat lampung dan transformasi arsitekturnya, kasus: perancangan
}

perahu, pemaknaan simbol naga dilambangkan dari kebijaksanaan, kekuatan, keberanian, kebaikan, dan keberuntungan. Pemaknaan lain dari simbol dua naga yang terdapat pada rumah Tinggi yaitu simbol dari manusia yang mencari inti kehidupan sebagai pencapaian manusia yang paling tertinggi ${ }^{7}$.

Dari pemaknaan diatas bahwa dapat disimpulkan makna dari bentuk perahu dan naga yaitu lebih merujuk pada budaya religi. Hal ini hampir sama dengan maksud pemaknaan dari pembahasan budaya agraris yang memiliki hasil pemaknaan pada religi. Pemaknaan dari perahu dan naga yaitu cenderung kpercayaan nenek moyang tentang alam atas (dunia) dan alam bawah (akhirat), serta lambang naga yang disebut sebagai lambang kekuasaan.

2. Unsur Budaya Agraris pada Rumah Perahu dan Rumah Tinggi

Budaya agraris yaitu suatu budaya yang berhubungan dengan tumbuh-tumbuhan dan dibudidayakan oleh masyarakat setempat. Budidaya tumbuh-tumbuhan tersebut berupa kebutuhan pokok manusia, kebutuhan pokok hewan dan maupun kebutuhan industri rumah tangga. Pada rumah Perahu dan rumah Tinggi, budaya agraris yang terdapat pada bagian rumah yaitu berupa motif sulur-suluran dan motif bunga. Adapun bagian-bagian yang terdapat motif sulur-suluran dan bunga antara lain sebagai berikut.

landmark lampung di Bakauheni, makalah dipresentasikan dalam simposium internasional jelajah arsitektur nusantara 2 (sijan 2), Institut teknologi Medan. Berastagi., 2003, hal. 6..

7 Miskaningsih, Makna simbolis ornamen pada bangunan utama vihara avaloktesvara di kawasan banten lama (skripsi), Universitas Negeri Yogyakarta, 2017, hal. 58. 
Tabel. Bagian-Bagian Rumah Yang

Terdapat Budaya Agraris Rumah Perahu Dan Rumah Tinggi

\begin{tabular}{|l|l|}
\hline No & $\begin{array}{c}\text { Bagian rumah Perahu yang terdapat } \\
\text { unsur agraris }\end{array}$ \\
\hline 1. & Tiang, terdapat motif sulur-suluran \\
\hline
\end{tabular}

Budaya agraris yang terdapat pada rumah Perahu dan rumah Tinggi berupa motif tumbuh-tumbuhan. Motif tumbuh-tumbuhan sendiri diambil dari berbagai jenis-jenis tumbuhan seperti bentuk daun, bunga dan batang. Kemudian distilir menjadi bentuk hiasan yang merambat bersulur meliuk kekiri dan kekanan ${ }^{8}$. Bentuk dari motif tumbuh-tumbuhan seperti sulur-suluran dan bunga. Tumbuhan sulur-suluran yaitu tumbuhan yang menyerupai tumbuhan paku, tumbuhan kangkung dan tumbuhan teraratai. Bentuk tumbuhan sulur-suluran yang terdapat di daerah Jambi dan Riau khususnya pada rumah Perahu di Desa Tanah Periuk dan rumah Tinggi di Desa Rokan Koto Ruang lebih dominan ke tumbuhan paku dan tumbuhan kangkung patah. Hal ini dapat dilihat pada bagian tiang rumah, anak tangga, badan tiang rumah, bagian pintu masuk dan jendela.

$$
\text { Motif sulur-suluran yang }
$$

berbentuk paku kacang belimbing menggambarkan falsafah orang Kerinci yang artinya, anak kandung menjadi tanggungan penuh, sedangkan kemenakan harus dimbimbing ${ }^{9}$. Selain itu sulur-suluran pada budaya Riau berbentuk kaluk paku merupakan bentuk pengayaan dari tumbuhan pakis yang bagi masyarakat Melayu Riau sebagai tumbuhan untuk sayur-mayur dan tanaman hias. Motif Kaluk Pakis dalam pandangan masyarakat Melayu Riau

${ }^{8}$ Ayu Kartini, Analisis penerapan ornamen bernuansa melayu ditinjau dari bentuk dan warna di Kota Medan (skripsi), Universitas Negeri Medan, 2014, hal. 13.

${ }^{9}$ Nusantara Knowladge, Arsiitektur nusantara: arsitektur tradisional palembang, jambi dan riau, denpasar, 2007, hal. 16. memiliki makna yang dalam bagi kehidupan masyarakatnya. Terutama pada kehidupan religi agama islam yang kuat dalam kesehariannya masyarakat MBdgian rRiaah Tèngagimbang adlapanotifur Kaluk Pakis. Motigr waikuk pakis bagis masyarakat Melayu Riau melambangkan Terdapat tjang yafsar barmotif sulyr-shluran kepada Tuhan Yang Maha Kuasa, Tuhan Seru Sekalian alam. Lingkaranlingkaran yang berbentuk spiral pada ujung setiap motifnya mencerminkan lingkaran dalam berbagai tingkatan alam yakni alam dunia, alam akherat dan alam akhir setelah nasib manusia ditentukan di Yaumil Mahsar, surga atau neraka ${ }^{10}$. Selain itu motif sulur-suluran yang terdapat di Riau diadopsi dari bentuk tumbuhan kangkung yang memiliki arti sebagai simbol semangat dalam menjalani hidup, terus berjuang pantang menyerah. Makna simbolik dari motif ini memberi pesan bahwa hidup ini banyak tantangan dan rintangan ${ }^{11}$.Motif tumbuh-tumbuhan menunjukkan simbol bahwa manusia sangat tergantung hidupnya dari tumbuh-tumbuhan $^{12}$. Dari pemaknaan diatas tentang motif tumbuh-tumbuhan yang terdapat dirumah Perahu dan rumah Tinggi dapat disimpulkan bahwa motif tumbuh-tumbuhan selain sebagai budaya agraris bagi kehidupan masyarakat, juga memiliki arti penting yang lain yaitu agama dan kepercayaan (religi). seperti contoh motif sulursuluran yang sebenarnya memiliki arti kehidupan yang akhirnya kembali kepada Tuhan Yang Maha Kuasa, Tuhan Seru Sekalian alam. Lingkaranlingkaran yang berbentuk spiral pada ujung setiap motifnya mencerminkan lingkaran dalam berbagai tingkatan alam yakni alam dunia, alam akherat dan alam

${ }^{10}$ Parwo Prihatin, Seni ornamen dalam konteks budaya melayu riau, 2007, Riau, hal. 7.

${ }^{11}$ Bambang Sungkowo. Peran ragam hias tradisional melayu riau pada desain produk kerajinan kayu di Pekanbaru. Jurnal vol 2. Universitas Negeri Padang, 2008, hal, 217.

${ }^{12}$ Muhammad Lufika Tondi dan sakura yulia iryani, Op. Cit, hal. 23. 
akhir setelah nasib manusia ditentukan di Yaumil Mahsar, surga atau neraka.

Dari pemaknaan diatas dapat disimpulkan bahwa pemaknaan motif sulur-suluran dan bunga ceplok cenderung ke budaya religi baik itu tentang ajaran agama bahkan kepercayaan tentang kekuasaan yang dimiliki oleh manusia. Kekuasaan yang dimaksud bisa berupa kekuasaan harkat dan martabat serta suatu wilayah yang biasanya dilambangkan dengan sosok pemimpin serta Raja.

3. Unsur Budaya religi Rumah Perahu dan Rumah Tinggi

Konsep religi menurut Koentjaraningrat yaitu terdapat tiga azas, (1) Teori-teori yang dalam pendekatannya berorientasi pada keyakinan dalam religi; (2) teori-teori yang dalam pendekatannya berorientasi pada sikap manusia terhadap alam ghaib atau hal ghaib; (3) teori-teori yang dalam pendekatannya berorientasi pada upacara religi ${ }^{13}$. Dari konsep religi yang diutarakan oleh Koentjaraningrat, bahwa bagian rumah Perahu dan rumah Tinggi terdapat unsur budaya religi yang akan dijelaskan pada tabel dibawah ini

Tabel. Bagian-Bagian Rumah Yang

Terdapat Budaya Religi Pada

Rumah Perahu Dan Rumah Tinggi.

\begin{tabular}{|l|l|l|}
\hline No & $\begin{array}{c}\text { Bagian } \\
\text { rumah } \\
\text { Perahu yang } \\
\text { terdapat } \\
\text { unsur religi }\end{array}$ & $\begin{array}{c}\text { Bagian rumah } \\
\text { Tinggi yang } \\
\text { terdapat unsur } \\
\text { religi }\end{array}$ \\
\hline 1. & $\begin{array}{l}\text { Umpak } \\
\text { rumah }\end{array}$ & Tiang rumah \\
\hline
\end{tabular}

Bagian-bagian rumah Perahu dan

rumah Tinggi yang terdapat unsur budaya religi memiliki pemaknaan pada setiap masing-masing bagian rumah tersebut. Pemaknaan bagian umpak rumah Perahu berdasarakan hasil dari

\footnotetext{
${ }^{13}$ Citra ayu pratiwi, Harai: Telaah Konsep Religi Koentjaraningrat. Universitas Airlangga, Surabaya, hal. 176.
}

wawancara dengan narasumber Bapak Lukman yaitu bermakna "tempat tumpuan mencencang, tempat landasan" yaitu adat bersendi syarak, syarak bersendi kitabullah. Artinya bahwa Dalam perkembangannya identitas Melayu-Islam berangkat dari seloko masyarakat Jambi, yakni "Adat bersendi syarak, syarak bersendi kitabullah", sebuah selogan yang sebenarnya berasal dari Minang Kabau. Seloko ini menunjukkan dua hal; pertama, adat Melayu Jambi bersumber dari al-Qur'an dan Sunnah; kedua, al-Qur'an dan Sunnah (tradisi Islam) terefleksi melalui adat Melayu Jambi ${ }^{14}$.

Keluwesan dan moderasi ini muncul sebagai akibat logis pengakuan masyarakat Melayu Jambi akan eksistensi adat dan syarak yang samasama dinilai benar dan sejalan, sehingga saling mengisi. Ini sesuai dengan apa yang diakatakan oleh seorang tokoh agama seperti Tarmizi bahwa slogan ini bermakna "bahwa prilaku masyarakat Jambi harus berlandaskan syara' atau hukum agama. Atau adat istiadat di jambi selalu bersinergi dengan syara', saling menopang dan memperkuat" ${ }^{15}$.

Selain pemaknaan budaya religi pada bagian rumah Perahu, pemaknaan budaya religi juga dilakukan pada rumah Tinggi. Hal itu dapat terdapat pada bagian tiang berdasarkan wawancara dengan Kepala Desa Rokan Koto Ruang, beliau mengatakan bahwa tiang rumah Tinggi memiliki slogan "Adat bersendi syarak, syarak bersendi Kitabullah". Dari slogan tersebut dapat diartikan bahwa dalam pandangan Melayu, jika terjadi pertentangan antara syara' dengan adat, maka adat harus mengalah dan syara' harus ditegakkan. Adat dalam masyarakat Melayu, baik secara langsung atau tidak langsung merupakan penjabaran dari

\footnotetext{
${ }^{14}$ Bahrun Ulum. PDF Politik Hukum Islam Melayu Jambi Adat Besendi Syarak, Syarak Besendi Kitabullah Dan Hubungannya dengan Upaya Kontekstualisasi Hukum Islam di Jambi, Bahrul Ulum, 2015, hal. 220.

${ }^{15}$ Bahrun Ulum, Ibid. halm 222-223.
} 
ajaran islam, sehingga dapat dikatakan kebudayaan Melayu itu sendiri bersebati dengan islam ${ }^{16}$. Selain itu, pemaknaan "Adat bersendi syarak, syarak bersendi Kitabullah". Artinya semua aspek budaya dan norma sosial masyarkat, wajib merujuk kepada ajaran islam dan dilarang bertikai apalagi menyalahi. Sebaliknya nilai budaya yang dianggap belum serasi dan belum sesuai dengan ajaran islam haruslah disesuaikan dengan islam, hal ini menjadi acuan bahwa islam tidak dapat dipisahkan dari adat atau norma-norma sosial lainnya dari suku Melayu Riau ${ }^{17}$.

\section{PENUTUP}

Unsur budaya yang terdapat pada rumah Perahu dan rumah Tinggi yaitu unsur agraris, unsur maritim dan unsur religi. Akan tetapi unsur budaya yang paling dominan yaitu unsur religi. Unsur religi menurut koentjaraningrat yaitu religi adalah sebagai bagian dari kebudayaan; dalam banyak hal yang membahas tentang konsep ketuhanan ${ }^{18}$. Hal ini dapat dilihat dari penjelasan unsur-unsur budaya yang terdapat ditabel di deskripsi atas. Pembangunan rumah Perahu dan rumah Tinggi berlandaskan pada kepercayaan dan agama. Pemaknaan setiap bagian rumahyang memiliki unsur religi tersebut dapat disimpulkan bahwa bagian umpak rumah Perahu dan tiang rumah Tinggi berlandaskan kepada " adat bersendi syarak, syarak bersendi kitabullah".

\footnotetext{
${ }^{16}$ Hasbullah. Dialektika Islam dalam budaya lokal: potret budaya melayu Riau. UIN Sultan Syarif Kasim, Riau, 2015, hal. 183.

${ }^{17}$ Husni Thamrin. Enkulturasi dalam Kebudayaan Melayu. UIN Sultan Syarif Kasim. Riau, 2017, hal. 99.

${ }^{18}$ Syarif Moeis, Religi sebagai salah satu identitas budaya (tinjauan antropologis terhadap unsur kepercayaan dalam masyarakat) universitas pendidikan indonesia bandung, 2008, hal. 1.
}

\section{DAFTAR PUSTAKA}

Ekomadyo, Agus S. 2003. Kayu Arra: Simbol Pohon Hayat Masyarakat Lampung Dan Transformasi Arsitekturnya, Kasus: Perancangan Landmark Lampung Di Bakauheni., Makalah Dipresentasikan Dalam Simposium Internasional Jelajah Arsitektur Nusantara 2 (Sijan 2). Institut Teknologi Medan. Berastagi.

Hasbullah. 2015. Dialektika Islam Dalam Budaya Lokal: Potret Budaya Melayu Riau. UIN Sultan Syarif Kasim. Riau.

Herusatoto, Budiono. 2008. Simbolisme Dalam Budaya Jawa. Jakarta: Hanindita.

Kartini, Ayu. 2014. Analisis penerapan ornamen bernuansa melayu ditinjau dari bentuk dan warna di Kota Medan (skripsi). Universitas Negeri Medan.

Knowladge, Nusantara. 2007. Arsitektur Nusantara: Arsitektur Tradisional Palembang, Jambi Dan Riau. Denpasar

Miskaningsih. 2017. Makna Simbolis Ornamen Pada Bangunan Utama Vihara Avaloktesvara Di Kawasan Banten Lama (Skripsi). Universitas Negeri Yogyakarta.

Mulyadi, Yadi. 2016. Kemaritiman, Jalur Rempah dan Warisan Budaya Bahari Nusantara. Universitas Hasanudin. Berkas pdf.

Noble G Allen. 2007. Traditional Buildings: A Global Survey of Structural Forms and Cultural Functions. New York: Palgrave Macmillan, a division of St Martin's Press. 
Noerwidi, Sofwan. 2014. Proses

Kolonisasi Bangsa Austronesia di Kawasan Maluku Utara.

Universitas Gadajah Mada.

Pratiwi ,Citra ayu. 2017. Harai: Telaah

Konsep Religi Koentjaraningrat.

Universitas Airlangga. Jurnal Japanology, Vol 5, No 2 MaretAgustus 2017. Surabaya.

Prihatin , Purwo. 2007. Seni Ornamen Dalam Konteks Budaya Melayu Riau. Jurnal Pengetahuan dan Pemikiran Seni. Riau.

Riany,Meta dkk. 2014. "Kajian Aspek Kosmologi-Simbolisme Pada Arsitektur Rumah Tinggal Vernakular di Kampung Naga". Jurnal Reka Karsa Vol. 2 No.4 Desember .2014.

Sari, Fillia Mutiara dan Dhani Mutiari. 2014.'Perbandingan Rumah Tinggal Tradisional Jawa dan Rumah Tinggal Modern di Surakarta". Jurnal Sinetika Vol. 14 No. 2. 2014.

Suharjanto, Gatot. 2014. "Konsep Arsitektur Tradisional Sunda Masa Lalu Dan Masa Kini”. Jurnal ComTech Vol. 5 No.1. 2014.

Sungkowo, Bambang. 2008. Peran ragam hias tradisional melayu riau pada desain produk kerajinan kayu di Pekanbaru. Jurnal vol 2. Universitas Negeri Padang.

Susannawaty, Anne. 2008. Kajian Bentuk Dan Makna Simbolik Figurin Gerabah Majapahit: Periode Hayam Wuruk 1350-1389 Masehi. Jurnal Vol 2. 123-140. Institut Teknologi Bandung.

Sutrisna, Deni dan Ery Soedewo. 2004. Laporan Penelitian Arkeologi, di Kabupaten Rokan Hulu, Provinsi Riau.
Syarif Moeis. 2008. Religi Sebagai Salah Satu Identitas Budaya (Tinjauan Antropologis Terhadap Unsur Kepercayaan Dalam Masyarakat) Universitas Pendidikan Indonesia Bandung.

Thamrin, Husni. 2017. Enkulturasi dalam Kebudayaan Melayu. UIN Sultan Syarif Kasim. Riau.

Tondi , Muhammad Lufika Dan Sakura Yulia Iryani. 2018. Nilai Dan Makna Kearifan Lokal Rumah Tradisional Limas Palembang Sebagai Kriteria Masyarakat Melayu. Vol 5. No 1. Langkau Betang.

Tjahjono, Gunawan. 2002. Indonesia Heritage: Arsitektur. Jakarta: Buku Antar Bangsa.

Ulum, Bahrun. 2015. Politik Hukum Islam Melayu Jambi Adat Besendi Syarak, Syarak Besendi Kitabullah Dan Hubungannya Dengan Upaya Kontekstualisasi Hukum Islam Di Jambi. Dalam Vdocument.

Umar, Muhammad Zakaria. 2016. "Koeksistensi Konsep Makna Simbolik Rumah Tradisional Buton (Rumah Kaum Maradika) Dengan Kantor BKDD di Kota Baubau". Jurnal Ilmiah Mustek Anim Ha Vol. 5 No. 1 April 2016.

Wawancara. Bapak Alex (Kepala Desa) Rumah Tinggi Rokan Koto Ruang. 28 Maret 2019.

Wawancara. Bapak Iskandar Rumah Perahu Tanah Periuk. 15 Februari 2019.

Wawancara. Bapak Lukman Rumah Perahu Tanah Periuk. 15 Februari 2019.

Wawancara. Bapak Samsisani Rumah Tinggi Rokan Koto Ruang. 28 Maret 2019. 
128 Arsitektur Rumah Perahu...

Wawancara. Bapak Untung Rumah Tinggi Rokan Koto Ruang. 28 Maret 2019.

Wawancara. Datuk Rio Helmi (Kepala Desa) Desa Tanah Periuk. $\quad 15$ Februari 2019.

Wawancara. Ibu Khadijah Rumah Perahu Tanah Periuk. 16 Februari 2019.

Wawancara. Ibu Sri Marlina (Juru Pelihara) Rumah Tinggi Rokan Koto Ruang. 28 Maret 2019. 